\title{
Distributions of Stream Fishes and their Relationship to Stream Size and Hydrology in Michigan's Lower Peninsula
}

\author{
TROY G. ZORN* \\ Michigan Department of Natural Resources, Hunt Creek Fisheries Station, \\ 1581 Halberg Road, Lewiston, Michigan 49756, USA \\ Paul W. SeElbach \\ Michigan Department of Natural Resources, Institute for Fisheries Research, \\ 212 Museums Annex Building, Ann Arbor, Michigan 48109-1084, USA \\ Michael J. Wiley \\ University of Michigan, School of Natural Resources and Environment, \\ 170 Dana Building, Ann Arbor, Michigan 48109-1115, USA
}

\begin{abstract}
We examined the distribution and abundance patterns of 69 fish species that commonly occur in the rivers of Michigan's lower peninsula to develop a simple, empirically based model for describing fish assemblages. We used cluster analysis to group fishes that shared similar abundance patterns at 226 stream sites. The 17 clusters we identified explained about $39 \%$ of the variation in species abundances among the stream sites, providing a reasonable, albeit simplified, picture of general associations of fishes in lower Michigan streams. Known ecological differences among species and further analyses suggested that a measure of cluster abundance should not be used to predict the abundances of its constituent species. We selected catchment area (CA) and low-flow yield (LFY; 90\% exceedence flow divided by catchment area) as axes for plotting fish distributions and rivers because these variables link catchment-scale features of the landscape to multiple, site-scale characteristics of stream habitat (e.g., temperature, velocity, and depth) important to fishes. As a measure of groundwater loading to streams, LFY, which integrates the geological, landform, and soil characteristics of catchments, reached its highest values in basins predominated by highly permeable soils and relatively steep topography. Plots of fish clusters and species abundances on LFY-CA axes provided insight into the structure of fish assemblages in lower Michigan streams. When plotted on LFY-CA axes, the 17 fish clusters were distributed in a meaningful pattern that reflected stream size and temperature preferences of constituent species. The LFY-CA axes provided an empirically derived framework for comparing Michigan streams and for assessing the physical and biological potential of different river reaches. This has allowed fishery managers to better explain, justify, and build public support for river management plans and actions. Although the relationships among LFY, CA, and fish abundances we describe are specific to lower Michigan streams, our approach could be used to develop similar models specific to other regions.
\end{abstract}

Fishery management activities on rivers usually focus on specific sites or short reaches. The extent to which successful management actions (e.g., stocking or targeted removals) at one locale can be prescribed for sites in different areas is often limited by the lack of a clear basis for evaluating the ecological similarity of managed sites in a way that is relevant to fish populations. The situation is especially problematic in glaciated regions like the upper Midwest where tremendous heterogeneity in landform and hydrology leads to large, but natural, spatial variability in fish assemblage composition (Wiley et al. 1997; Zorn et al. 1998). For

\footnotetext{
* Corresponding author: zornt@state.mi.us
}

Received April 10, 2000; accepted July 27, 2001 example, among rivers in Michigan's lower peninsula (lower Michigan), million-fold differences in low-flow yields $(90 \%$ exceedence flow divided by catchment area) and 2-3-fold variation in daily average temperature $\left(10-26^{\circ} \mathrm{C}\right)$ in July help shape fish assemblages at unimpaired stream sites having as few as 1 to as many as 45 species (Zorn et al. 1998). Identifying key variables that shape the physical habitat template (as defined by Southwood 1977) for fish populations is particularly desirable in these settings because it can lead to easily applied models for evaluating the ecological potential of a site to support species of interest. To the extent that strategic planning for riverine fisheries is desirable in large, diverse regions (e.g., states and provinces), some simplifying model of 
riverine habitat requirements seems a practical necessity.

Classification and ordination are quantitative tools commonly used for reducing ecological complexity (Strauss 1982; Pielou 1984; Aadland 1993). In this paper, we use cluster analysis to identify groups of fishes having similar spatial patterns of distribution and abundance (i.e., macrohabitat guilds) across a set of 226 stream sites sampled throughout lower Michigan. Because groupings defined by cluster analysis may have limited statistical validity (Strauss 1982), we use additional statistical techniques to determine (1) how well the guilds (clusters of taxa) explain observed variation in abundance of fishes among sites and (2) whether guild abundance could serve as a surrogate for describing abundances of constituent species. We then ordinate the resulting clusters using simple, catchment-scale habitat axes (catchment area and low-flow yield) that index site-scale habitat features (habitat volume, temperature, and flow stability) known to be important in structuring fish assemblages of this region (Hendrickson and Doonan 1972; Aadland 1993; Poff and Allan 1995; Lyons 1996; Wiley et al. 1997; T. C. Dewberry, Pacific Rivers Council, unpublished). Finally, we describe some of our experiences using this simple ordination-based empirical model in regional fisheries management and restoration settings.

\section{Methods}

\section{Michigan Rivers Inventory Data}

We obtained data for this study from the Michigan Rivers Inventory (MRI) database, which contains catchment-based characterizations of 675 sites in lower Michigan (Seelbach and Wiley 1997). Data available for MRI sites included general catchment characteristics (e.g., geology, climate, land use, topography), various reach-scale and site-scale habitat features, measured and predicted exceedence flows, measured and predicted July temperatures, and fisheries survey data (Seelbach and Wiley 1997). Abundance data for fishes were obtained from rotenone and multiple-pass electrofishing depletion surveys conducted during summers from 1982 to 1995 at 226 MRI sites (Figure 1). Presence-absence data were used to note occurrence of fishes at additional sites where abundance data were not available. Seelbach and Wiley (1997) and Seelbach et al. (1988) provide greater detail regarding fish sampling techniques and computation of abundance estimates.

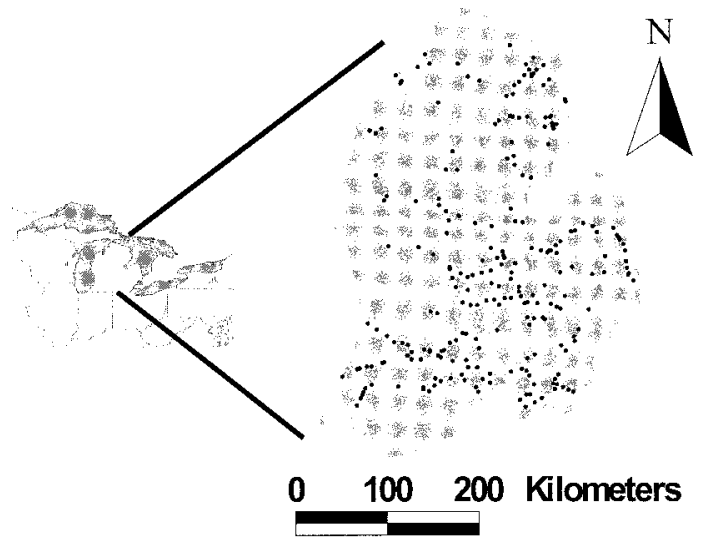

FIGURE 1.-Map showing the major river drainages of Michigan's lower peninsula and locations of the 226 fish sampling sites included in this study.

The 226 sites with assemblage-level data provided an excellent sample of lower Michigan streams, with a few caveats. Small streams were somewhat undersampled, given their abundance in the landscape (Figure 2). Fish standing crop (weight per unit area) estimates from the rotenone surveys may represent only about $75 \%$ of actual values because of sampling inefficiency (Seelbach et al. 1994). To make abundance estimates of all species captured, we assumed equal catchability of all fishes at electrofishing depletion sites (Zippen 1958). There undoubtedly was variation in catchability among species. Because each site was sampled for fishes only once, these data do not capture temporal variation that obviously exists. Temporal variation not accounted for will appear in our analyses as residual spatial error (Wiley et al. 1997). However, we believed that although any individual sample may not perfectly represent a site's typical fish assemblage, the existence of fish assemblage data from 226 sites essentially provided replicate samples for many types of lower Michigan rivers. In addition, we expected patterns at a regional scale to be dramatic enough (e.g., contrasts of high versus low versus zero abundance levels) that any sampling-induced biases would not significantly alter our findings.

\section{Cluster Analysis}

We used cluster analysis to group 69 fishes into guilds based on correlations among their standing crops at 226 sites. To exclude rare species from the analysis, we only used fishes that occurred at nine or more sites or had a total abundance in the data set of at least $7.0 \mathrm{~kg} / \mathrm{ha}$. The data were stan- 


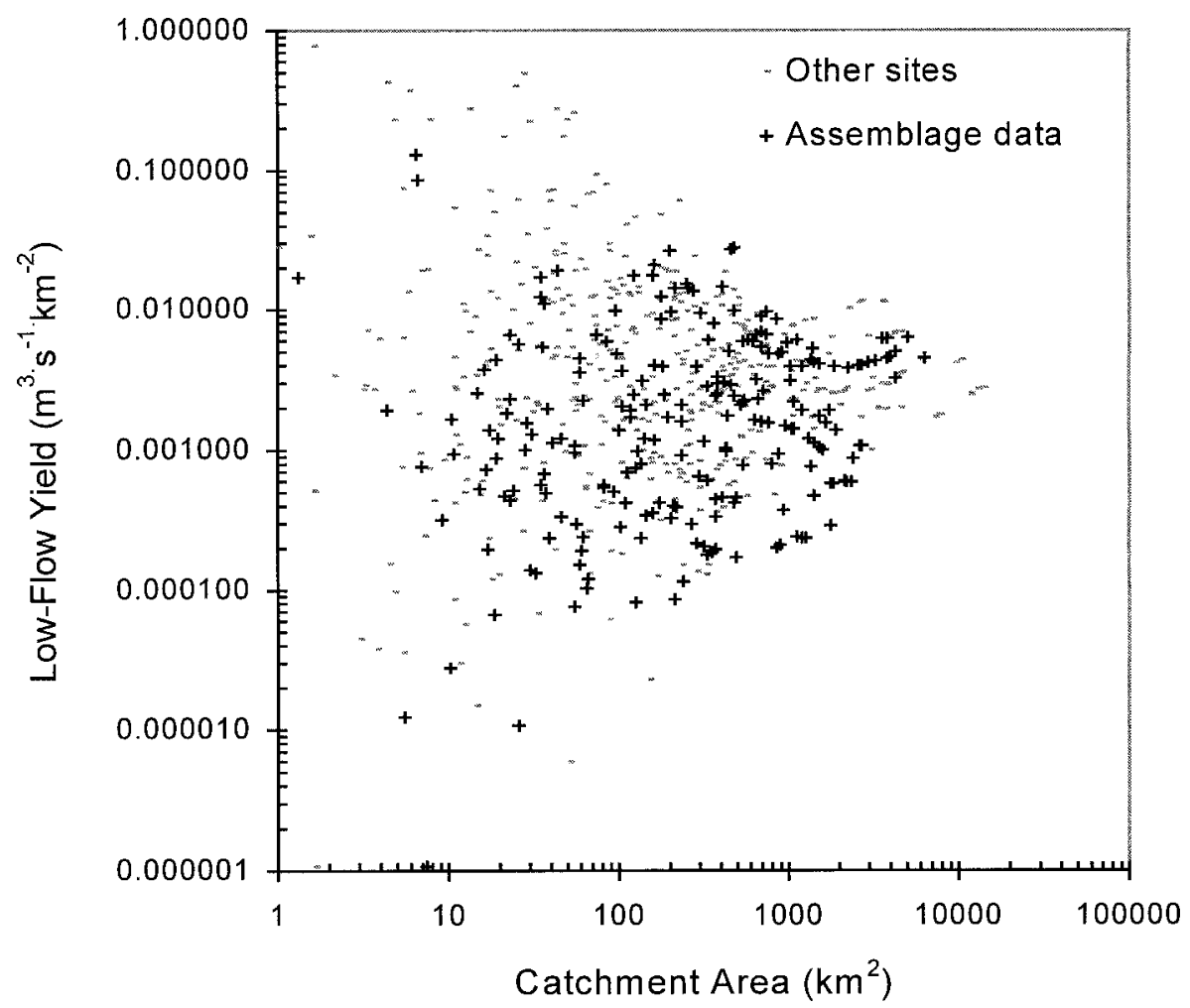

FIGURE 2.-Low-flow yield and catchment area values for 226 sites on lower Michigan rivers having biomass estimates for the entire fish assemblage (assemblage data sites) and an additional 449 Michigan Rivers Inventory sites lacking such data (other sites).

dardized (Z-distribution, mean $=0, \mathrm{SD}=1$ ) by species so that body-size differences among fishes would not influence the clustering process. We used the complete linkage clustering method and Pearson's correlation distance measure, both recommended for clustering variables (SPSS 1993). We identified 17 clusters of fishes for use in subsequent analyses (Table 1), and a dendrogram from the cluster analysis is shown in Figure 3.

We used analysis of variance (ANOVA) to assess how well the 17 clusters explained species distributions within the data set. For each of 70 randomly selected sites, we calculated the amount of variation in species abundances (standardized as $Z$-scores) explained by the clusters. Using cluster membership as the grouping variable for species at each site, we calculated the proportion of variance explained by the clusters $\left(R^{2}\right)$ by dividing the between-groups (i.e., between clusters) sum of squares by the total sum of squares (Table 2). This produced an $R^{2}$ value for each of the 70 sites. The average of all the $R^{2}$ values provided an estimate of the overall fit of the clusters to the data set.
We then evaluated how adequately a measure of a cluster's abundance would represent the abundances of its constituent species. We hypothesized that if a cluster's abundance adequately represented abundances of its constituent species, then equal slopes would exist for simple linear regressions between a cluster's abundance (the independent variable) and the abundances of each of its constituent species. Differences among slopes would indicate that abundances of all fishes in a cluster did not vary proportionately among sites. To test this hypothesis, we first calculated fish cluster scores for each of the 17 clusters. The fish cluster score was the average of the $Z$-scores for cluster members at the site. A cluster score was calculated only when abundance data existed at the site for at least half of the cluster members. This strengthened our analysis by enabling us to include additional MRI sites, when sufficient abundance data existed, and to exclude sites where abundance estimates were lacking. Then, for each cluster, we computed a set of regression equations between cluster scores and the $Z$-scores of its con- 
TABLE 1.-Clusters of fishes from lower Michigan streams identified by hierarchical cluster analysis. The species name in bold type is used to identify clusters in the text and figures. Asterisks denote clusters that had significant $(P$ $\leq$ 0.05) differences among slopes in regressions of species' Z-scores against the cluster score.

1. Creek chub* Semothilus atromaculatus Redfin shiner Lythrurus umbratilis Central stoneroller Campostoma anomalum Common shiner Luxilus cornutus Bluntnose minnow Pimephales notatus Johnny darter Etheostoma nigrum

2. Brook stickleback* Culea inconstans Hybrid sunfish Northern redbelly dace Phoxinus eos Bluegill Lepomis macrochirus

3. Mottled sculpin Cottus bairdi Blacknose dace Rhinichthys atratulus

4. White sucker* Catostomus commersoni Fathead minnow Pimephales promelas

5. Burbot Lota lota Longnose dace Rhinichthys cataractae

6. Brown trout* Salmo trutta Rainbow trout Oncorhynchus mykiss Chinook salmon Oncorhynchus tshawytscha

7. Brook trout* Salvelinus fontinalis Slimy sculpin Cottus cognatus Coho salmon Oncorhynchus kisutch

8. Black bullhead Ameiurus melas Yellow bullhead Ameiurus natalis Green sunfish Lepomis cyanellus

9. Northern pike* Esox lucius Central mudminnow Umbra limi Bowfin Amia calva Pumpkinseed Lepomis gibbosus Golden shiner Notemigonus crysoleucas Pirate perch Aphredoderus sayanus Blackside darter Percina maculata
10. Walleye* Stizostedion vitreum Flathead catfish Pylodictis olivaris White crappie Pomoxis annularis Common carp Cyprinus carpio Black crappie Pomoxis nigromaculatus Spotted sucker Minytrema melanops Tadpole madtom Noturus gyrinus

11. Freshwater drum Aplodinotus grunniens Quillback Carpoides cyprinus Gizzard shad Dorsoma cepedianum

12. Logperch* Percina caprodes Channel catfish Ictalurus punctatus Spotfin shiner Cyprinella spiloptera Brook silverside Labidesthes sicculus Mimic shiner Notropis volucellus Shorthead redhorse Moxostoma macrolepidotum Sand shiner Notropis stramineus

13. Hornyhead chub* Nocomis biguttatus Grass pickerel Esox americanus Lake chubsucker Erimyzon sucetta

14. Rock bass* Ambloplites rupestris Brown bullhead Ameiurus nebulosus Longear sunfish Lepomis megalotis Largemouth bass Micropterus salmoides Rainbow darter Etheostoma caeruleum

15. Smallmouth bass* Micropterus dolomieu Black redhorse Moxostoma duquesnei Striped shiner Luxilis chrysocephalus River chub Nocomis micropogon Northern hog sucker Hypentelium nigricans Stonecat Noturus flavus Greenside darter Etheostoma blennioides

16. Yellow perch Perca flavescens Rosyface shiner Notropis rubellus

17. Silver redhorse Moxostoma anisurum Greater redhorse Moxostoma valenciennesi Golden redhorse Moxostoma erythrurum stituent species, and noted when at least two slopes differed within each set of equations at a $P$-value of 0.05 (Figure 4). We did not consider this a very conservative test of a cluster's predictive power because each cluster score was initially calculated from $Z$-scores of its constituent species. Thus, by definition, the cluster and species scores should be correlated. Therefore, differences among slopes within a set of regressions would strongly suggest that the cluster score might not equally represent abundances of its constituent species.

\section{Ordination}

We selected low-flow yield (LFY) and catchment area $(\mathrm{CA})$ as the primary ordination axes for streams and their fish assemblages. We defined a site's LFY as the $90 \%$ exceedence-flow discharge divided by its CA. The ability of LFY and CA to integrate many site-scale habitat features important to fishes makes these measures particularly useful as habitat axes.

Low-flow yield.-We used LFY as the first major stream habitat axis. It is a measure of the contribution of groundwater to nonregulated rivers and reaches its highest levels in basins with highly permeable surface geology and steep topography (Hendrickson and Doonan 1972). As such, LFY captures much variation in water temperatures among streams in glaciated Midwestern states such as Michigan (Hendrickson and Doonan 1972; 


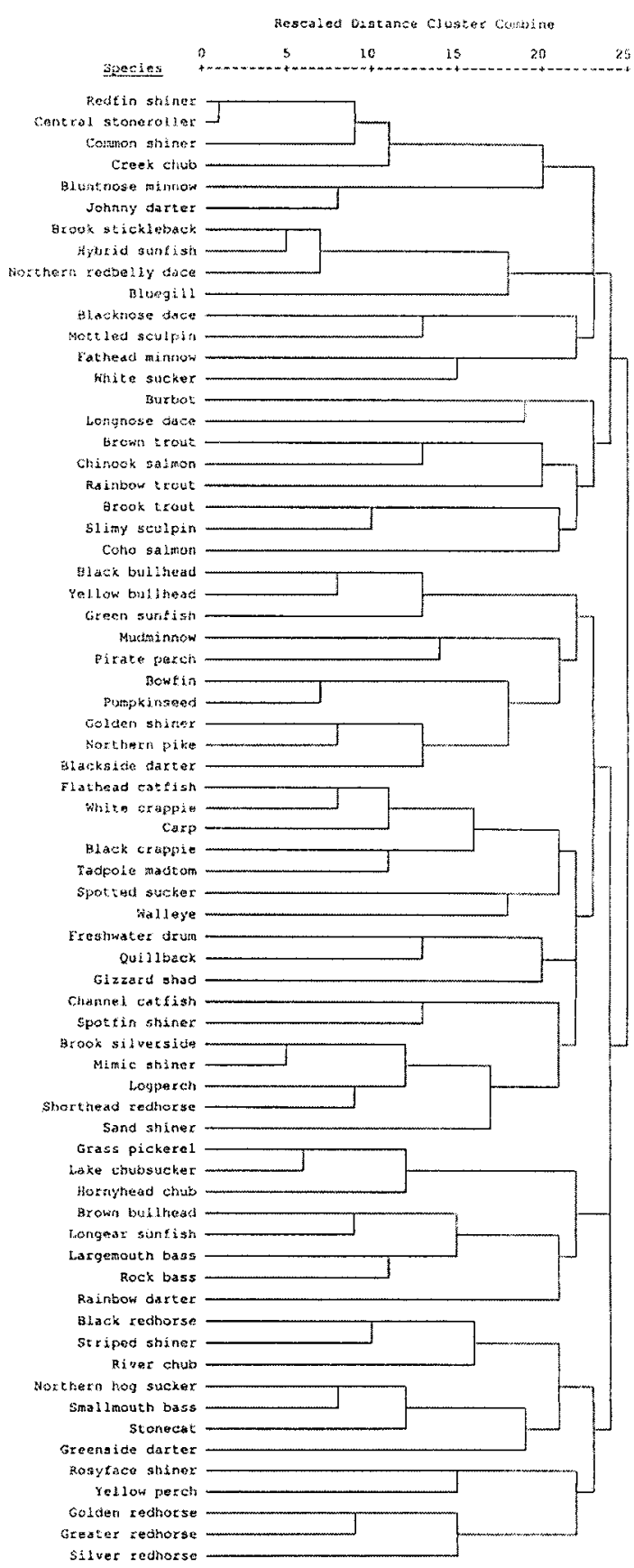

Figure 3.-Dendrogram from hierarchical cluster analysis of 69 common fishes at 226 lower Michigan sites having abundance data for the entire fish assemblage. Species abundances were standardized to a $Z$ distribution $($ mean $=0, S D=1)$. The complete linkage clustering method and Pearson distance measure were used.
TABLE 2.- Sample data and analysis of variance outputs demonstrating how $R^{2}$ values were calculated for a site by using fish abundance and cluster membership data. Data for site $X$ are fish abundances expressed as $Z$-scores.

\begin{tabular}{ccc}
\hline Species and statistics & Cluster & $\begin{array}{c}\text { Abundance } \\
\text { at site } X\end{array}$ \\
\hline A & 1 & -0.2 \\
B & 1 & -0.4 \\
C & 1 & -0.3 \\
D & 1 & -0.1 \\
E & 2 & 0.8 \\
F & 2 & 1.2 \\
G & 3 & 0.0 \\
H & 3 & -0.1 \\
I & 3 & 0.2 \\
Between-clusters sum of squares & 2.12 & \\
Total sum of squares & 2.30 & \\
$R^{2}$ & 0.92 & \\
\hline
\end{tabular}
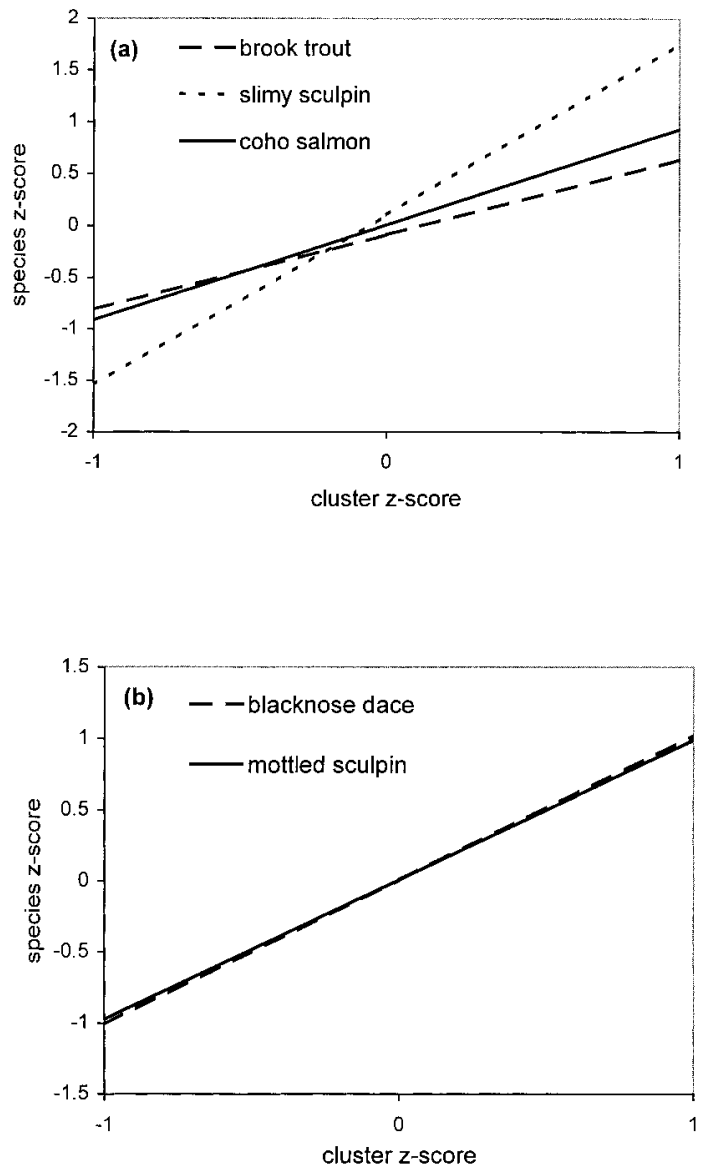

FIGURE 4.-Example comparisons of slopes of regressions between the $Z$-scores of selected fishes and the average $Z$-scores for two clusters: (a) the brook trout cluster, where significantly $(P<0.05)$ different slopes were indicated and (b) the mottled sculpin cluster, where slopes did not differ significantly. 
Wehrly et al. 1998; Dewberry, unpublished). In his classification scheme for Midwestern streams, Dewberry (unpublished) initially proposed LFY as an index of the stability of stream discharge and temperature regimes and used the index as an axis for characterizing a continuum of hydrologically different streams in Michigan.

Low-flow yield is an index of temperature, which is one of the major factors affecting fish growth (Brett 1979), survival (Matthews and Styron 1981; Smale and Rabeni 1995a), and distribution (Magnuson et al. 1979; Shuter et al. 1980; Legendre and Legendre 1984; Bowlby and Roff 1986; Meisner et al. 1987; Meisner et al. 1988; Staso and Rahel 1994; Smale and Rabeni 1995b; Peterson and Rabeni 1996). Not surprisingly, temperature has been identified as a key variable in many classifications of stream fishes (e.g., Huet 1959; Smith and Fisher 1970; Zalewski and Naiman 1985; Hawkes et al. 1986; Matthews and Robison 1988; Lyons 1989; Rahel and Hubert 1991; Degerman and Sers 1992; Lyons 1996; Dewberry, unpublished).

In addition to providing an index of a stream's thermal regime, LFY is correlated with a river's current velocity conditions during the growing season and its hydrologic stability or "flashiness" (Hendrickson and Doonan 1972). Summer streamflow and current velocity influence fish behavior at the individual level (e.g., Kalleberg 1958; Bachman 1984; Godin and Rangeley 1989; Zorn and Seelbach 1995). At the guild level, hydrologically stable (high-LFY) Midwestern streams generally favor fishes characterized as streamlined, piscivorous, intolerant of turbidity and silt substrates, and preferring moderate velocities (Poff and Allan 1995). As an index of hydrologic stability, LFY can be thought of as part of a habitat template (sensu Southwood 1977) favoring particular life history strategies (Poff and Ward 1989; Poff and Ward 1990; Schlosser 1990) and influencing lotic assemblage structure through time (Starrett 1951; Moyle and Li 1979; Poff and Ward 1989; Bayley and $\mathrm{Li}$ 1994).

Catchment area.-We used each site's catchment area (CA), a correlate of discharge and an index of stream size, as the second major stream habitat axis. We used CA to measure stream size, rather than stream order or width, because it is readily measured using geographic information system (GIS) techniques and provides a uniform understanding of stream size regardless of the scale of topographic maps or permanence of streams (Hughes and Omernik 1983).
Numerous early studies (Hynes 1970; Hawkes 1975) described changes in stream environments and communities, primarily along a longitudinal gradient from cold headwater streams to large warmwater streams; others examined upstreamdownstream patterns in warmwater streams. Distinctions between biotic zones in streams have been attributed to various factors that often change predictably in a downstream direction, such as current velocity, substrate, stream discharge, temperature, dissolved oxygen, dissolved nutrients, and biotic interactions (factors cited in various combinations by Huet 1959; Kuehne 1962; Smith and Fisher 1970; Hawkes 1975; Horwitz 1978; Vannote et al. 1980; Rose and Echelle 1981; Zalewski and Naiman 1985; Hawkes et al. 1986; Matthews and Robison 1988; Lyons 1989; Wiley et al. 1990; Rahel and Hubert 1991; Degerman and Sers 1992; Lyons 1996). Longitudinal changes in the temporal stability of stream environments are also thought to contribute to downstream changes in fish assemblage structure (Horwitz 1978; Vannote et al. 1980; Ward and Stanford 1983; Wiley et al. 1990). For example, CA is an index of the mean and daily variation in temperature during the growing season, both of which are important to stream fishes (Wiley et al. 1990; Gordon et al. 1992; Wehrly et al. 1998).

Plotting clusters.-The fish abundance data allowed us to quantify the quality of stream habitats for each fish cluster. We selected sites where each cluster was most abundant. Those sites had cluster scores 0.5 standard deviations or more above the mean cluster score for all sites. We then computed the geometric mean and standard deviation of LFY and CA values for each set of sites and used them as coordinates for ordinating clusters. This process was repeated for each of the 17 clusters. We used the same method to plot the mean and range in measured or predicted weekly temperatures for July at locations where clusters were most abundant.

Exploratory data analyses indicated that the MRI hydrology models (Wiley and Seelbach, unpublished data) underpredicted LFYs of some sites on very small (e.g., CA $<15 \mathrm{~km}^{2}$ ) trout streams and that these sites should not be included in ordinations. Examination of Michigan stream-gauge data from the U.S. Geological Survey revealed that substantial populations of salmonids did not occur in streams with an LFY of less than 0.0028 $\mathrm{m}^{3} \cdot \mathrm{s}^{-1} \cdot \mathrm{km}^{-2}$. Therefore, sites with predicted LFY values of less than that but having substantial trout populations ( $Z$-scores for brook and brown trout 


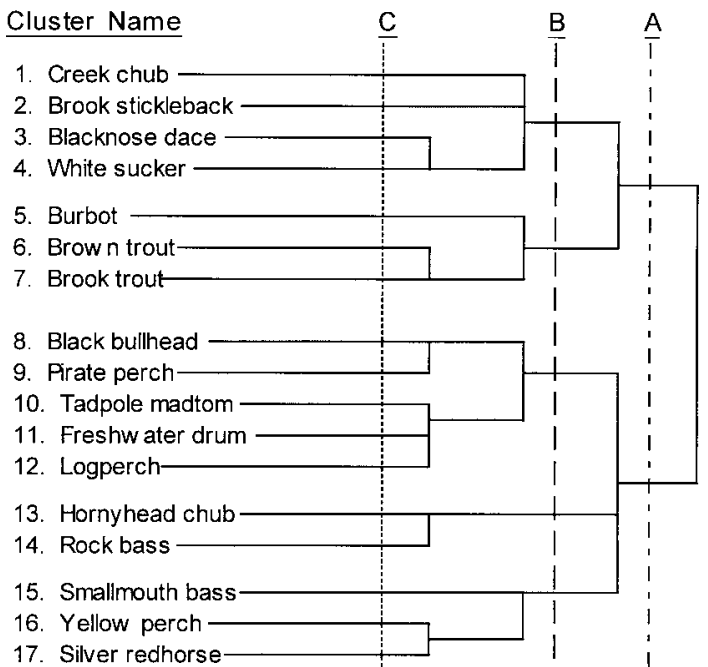

FIgURE 5.-Simplified dendrogram based on raw cluster analysis output from Figure 3. Letters A, B, and C identify levels of clustering (see text). Species names were used to represent clusters identified at level $\mathrm{C}$ in the dendrogram. Cluster membership is shown in Table 1 and Figure 3.

clusters greater than 0.5 standard deviations above the mean for all MRI sites) were considered outliers and were excluded.

\section{Results}

\section{Cluster Analysis}

Several interesting groupings emerged within the cluster hierarchy (Figures 3,5). The first split (A in Figure 5) appeared to generally separate fishes in small Michigan streams from those more typical of larger downstream reaches. The clusters identified at level B in Figure 5 appeared to reflect the thermal and stream-size requirements of individual species. For example, clusters containing species typical of small- to medium-sized coldwater streams (brook trout, brown trout, and burbot clusters), those having species typical of smallto medium-sized cool streams (hornyhead chub and rock bass clusters), and those having species typical of medium to large, warmwater streams (walleye, freshwater drum, logperch, northern pike, and black bullhead clusters) are grouped at this level.

We selected the 17 clusters identified at level C for further analysis because we thought they would be useful in a management context (Figure 5; Table 1). Species clustered at this level often shared fairly distinctive habitat requirements based on life history accounts such as Trautman (1981) and
Becker (1983). As at level B, membership of species in clusters at level C (Table 1) seemed to reflect similar preferences among fishes for particular stream temperature and size conditions in Michigan rivers. For example, fishes that often are most abundant in small, runoff-dominated streams (creek chub cluster) were separated from those more typical of small streams with some groundwater inputs (mottled sculpin cluster). Brook trout and slimy sculpin, fishes characterized as being most typical of very small, highly groundwaterfed streams, were grouped at level C. Species typical of large-sized warmwater streams were grouped into several clusters (e.g., freshwater drum, logperch, and silver redhorse clusters). Membership of fishes in some clusters seemed to reflect shared preferences for specific habitats such as wetlands (northern redbelly dace cluster), vegetated floodplains (northern pike cluster), and the Great Lakes (freshwater drum cluster).

The proportion of variation in fish collections at 70 sites explained by species membership in the 17 clusters averaged 0.39 . Thus, the clusters provided a reasonable, albeit simplified, picture of general associations of fishes in lower Michigan streams. However, considerable variation within the data remained unexplained.

Regressions of cluster scores against constituent species $Z$-scores suggested that a single measure of cluster abundance should not be used to predict the abundances of a cluster's constituent species. There were significant differences in regression slopes among cluster members for 11 of the 17 clusters examined (Table 1). These clusters comprised 54 of the 69 species studied. The absence of significantly different slopes among the other six clusters could result from member species sharing similar abundance patterns or could be related to the small size of these clusters and the proportionately greater influence of member-species abundances on the cluster score. A lack of significantly different slopes occurred only among clusters having three or fewer species (Table 1).

\section{Ordination}

The 17 habitat-preference guilds were arrayed in a biologically interpretable fashion when their LFY and CA optima (defined as mean LFY and CA conditions of highest cluster abundance) were plotted on axes of LFY and CA (Figure 6). For example, coldwater fishes, such as those in the brook trout and brown trout clusters, generally were restricted to small-CA, high-LFY streams; fishes typical of warm headwaters, such as those 


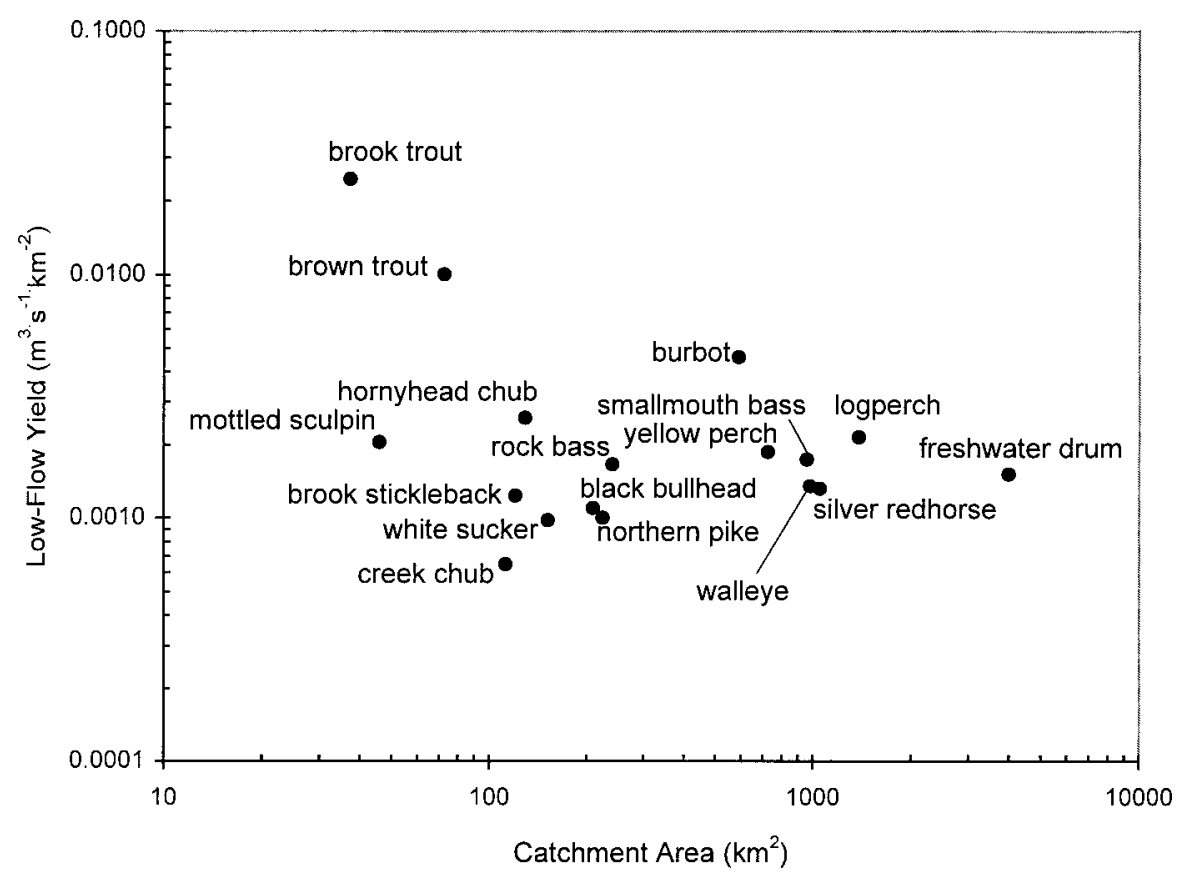

Figure 6.- Mean low-flow yield (LFY) and catchment area (CA) conditions of sites on lower Michigan streams where each of 17 clusters was most abundant (i.e., sites having cluster $Z$-scores of 0.5 SD or more above the mean cluster $Z$-score for all sites).

in the creek chub and brook stickleback clusters, were found in the small-CA, low-LFY portion of the graph. Small streams with intermediate LFY conditions supported coolwater fishes, such as those in the mottled sculpin and hornyhead chub clusters.

Cluster optima were closer together on the LFYaxis as stream size increased. Still, there appeared to be separation of guilds, those containing mostly coolwater fishes (e.g., burbot and rock bass clusters) having optima in higher LFY streams and more lentic clusters (e.g., black bullhead and northern pike clusters) having optima in low-LFY streams (Figure 6). Low-flow yield optima for clusters of fishes most abundant in larger streams (i.e., logperch, walleye, smallmouth bass, yellow perch, and silver redhorse clusters) fell within an even smaller range of LFY values. This largely reflected the reduced range in LFY values among streams of this size (Figure 2).

To explore the discreteness of the clusters, we plotted the mean LFY and CA conditions where each cluster was most abundant $( \pm S D$; Figure 7$)$. Considerable overlap in distributions occurred among most clusters; however, little or no overlap occurred among those at the extremes of LFY and CA (Figure 7). The extent of overlap seemed in- dicative of how frequently individual species from different clusters would coexist. For example, in Michigan rivers, members of the mottled sculpin cluster commonly coexisted with members of the brown trout cluster, but rarely coexisted with members of the walleye cluster. In addition, highest standing crop and species richness values for fishes occurred in Michigan rivers that had LFY-CA conditions similar to those where cluster overlap was greatest (Zorn et al. 1998).

\section{Discussion}

\section{Cluster Analysis}

The results of the clustering and ordination of macrohabitat guilds reported here bear many similarities to classifications developed in other regions. For example, Ricker's (1934) classification of Ontario streams separated streams into groups based on their size and thermal conditions. Many of the characteristic fishes (dace, trout, black bass, pickerel, and catfish) used in classifying Maryland streams (Van Deusen 1954) were similar to clusters we identified. Correspondence analysis of stream fishes in Wisconsin (Lyons 1989) identified water temperature, stream gradient, substrate composition, and shoreline vegetation as being im- 


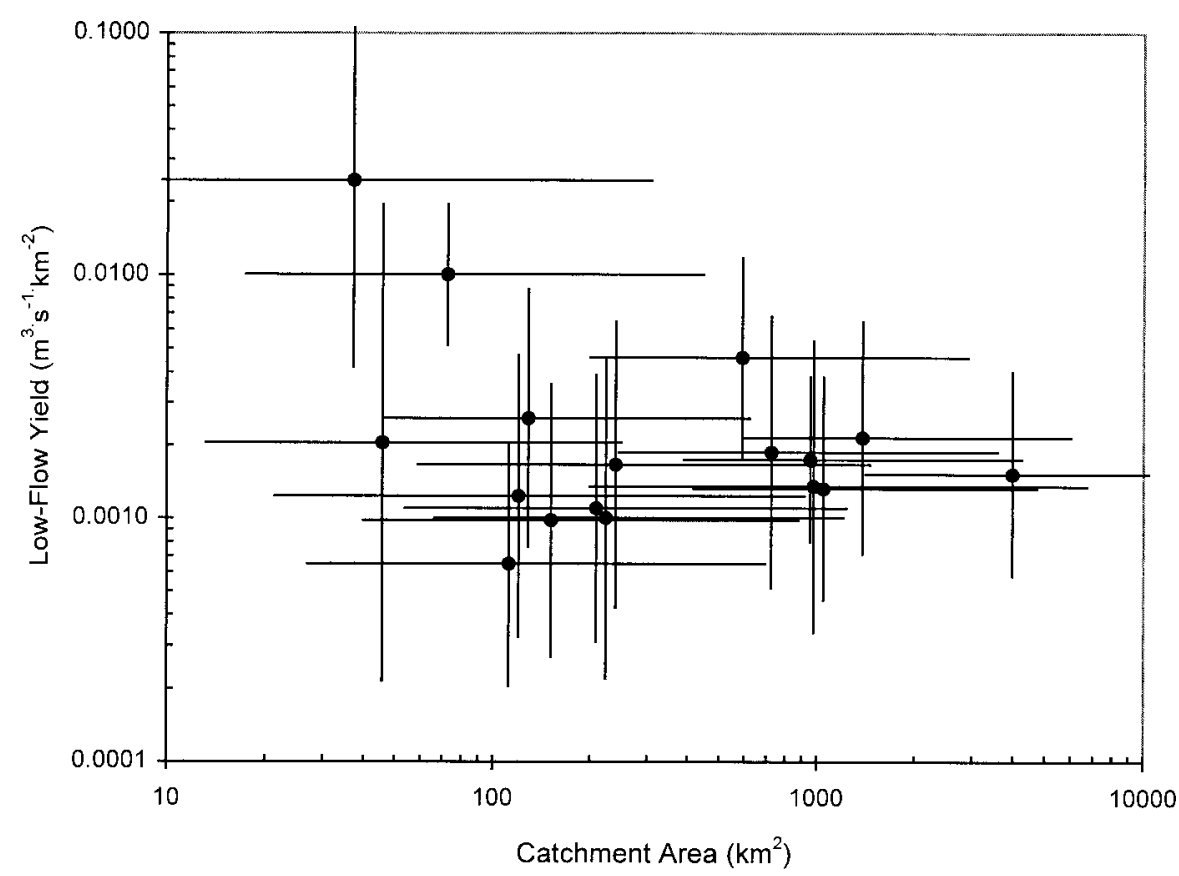

FIgURE 7.- Mean and standard deviation of low-flow yield (LFY) and catchment area (CA) conditions of sites on lower Michigan streams where each of 17 clusters was most abundant. Identity of clusters is shown in Figure 6.

portant in determining species associations. General associations among fishes in Lyons' study included (1) trout, dace, and sculpin; (2) northern redbelly dace and brook stickleback; and (3) sunfishes and bullheads. Halliwell (1989) combined Massachusetts fishes into groups that seemed to reflect shared preferences among species for particular temperature, stream size, and current velocity. He identified five associations: (1) small, upland coldwater fishes, including natural reproducing salmonids; (2) a marginal trout community with a few large trout, blacknose dace, and longnose dace; (3) a coolwater group including smallmouth bass, rock bass, and darters; (4) a warmwater lentic group containing sunfishes and bullheads; and (5) a lowland assemblage containing pickerel and chubsuckers. Aadland (1993) identified similar groupings of fishes in Minnesota streams and related their habitat-use patterns to depth and current velocity, both correlates of river size and hydrology. Although our findings generally seemed to corroborate other studies, direct comparisons of cluster membership are difficult because of regional differences in available species pools and types of streams examined.

\section{Ordination}

The distribution of fish macrohabitat guild (cluster) "optima" (i.e., with respect to LFY and CA) suggested that fish assemblage structure changes dramatically along both axes. Optima were most widely spaced on the LFY-axis in small streams, but converged with increasing CA (Figure 6). This seemed to reflect the fact that both hydrologic and thermal characteristics of Michigan streams tend to reach extremes of either stability or instability in headwater reaches. High-LFY, headwater streams were predominated by coldwater stenothermic fishes in the brook trout and brown trout clusters. Species more tolerant of warm, physically variable, low-velocity pool environments, as represented by the brook stickleback, creek chub, and white sucker clusters, were most abundant in lowLFY headwater streams.

A variety of factors may explain why most headwater species were not abundant farther downstream (Figure 6). Reduced abundances of coldwater fishes may reflect species intolerance to warmer conditions downstream or biotic interactions with species better adapted to larger or thermally different stream environments (Waters 1983; 


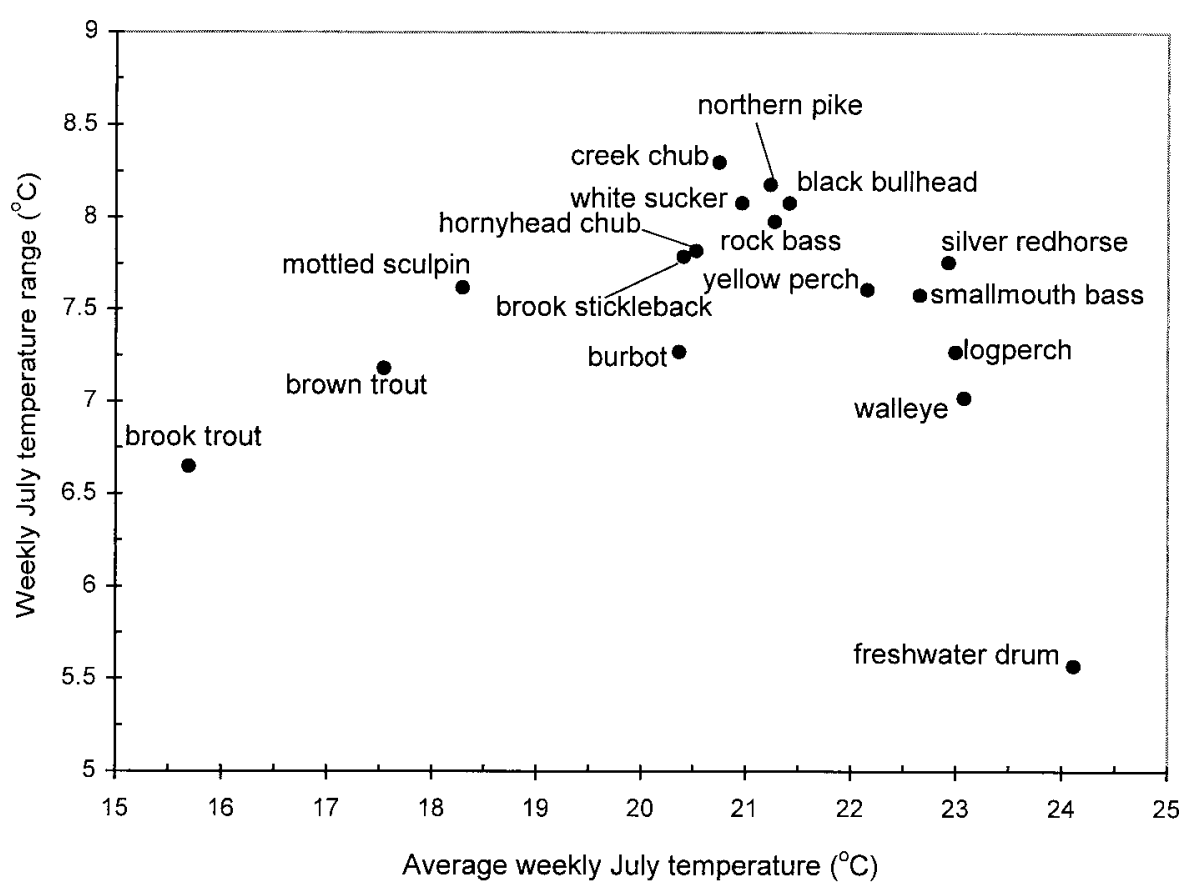

FIGURE 8.-Predicted mean and range in July weekly temperatures of lower Michigan stream sites where each of 17 clusters was most abundant (i.e., sites having cluster $z$-scores $\geq 0.5 \mathrm{SD}$ above the mean cluster score for all sites).

Larson and Moore 1985; Staso and Rahel 1994). High tolerances of some headwater fishes for extreme temperature and dissolved oxygen conditions (Matthews and Styron 1981; Smale and Rabeni 1995a, 1995b) suggest that they also should thrive in the relatively benign conditions of downstream reaches. Biotic interactions or other factors may prevent these fishes from being abundant in larger streams. Some examples of thermally tolerant, headwater species mentioned in the literature as being susceptible to predation or being inferior competitors include central stoneroller (Power et al. 1985), fathead minnow (Becker 1983), creek chub (Becker 1983), and white sucker Catostomus commersoni (Schlosser 1987). A lack of deeper pool habitats or the presence of other physical conditions unsuitable for adult piscivores may allow such fishes to thrive in headwater environments (Schlosser 1987).

Convergence in the physical characteristics (Figure 2) and fish assemblages (Figure 6) of lower Michigan streams occurred with increasing CA values. This attenuation of variability often results from the accumulation of many hydrologically different patches of glacial drift as streams (and their catchments) grow in size. Streams draining the smallest catchments, where pure deposits of the most permeable or least permeable glacial deposits occur, represent the extremes of hydrologic stability or instability. However, as catchment size increases, hydrologically different patches of drift are often added to the catchment and their hydrologic effects blend. This blending effect generally results in decreased variation in physical conditions and associated fish communities with increasing stream size. Also, in large streams, discharge volume itself becomes an important variable influencing the thermal and hydrologic stability of habitat characteristics (Gordon et al. 1992).

Because it reflects summer (growing season) conditions, LFY is correlated with other proximal variables that have energetic importance to fishes, including temperature (Zorn et al. 1998) and dissolved oxygen (Hendrickson and Doonan 1972; Brett 1979; Wiley et al. 1990). In this regard, the LFY-CA template could be thought of as an index of summer thermal environments available in lower Michigan rivers. Linkage among LFY, CA, and stream temperature is supported by the similarity of spatial relationships among fish clusters when plotted on either LFY-CA or summer stream temperature axes (Figure 8). However, local-scale factors may sometimes weaken linkages between 


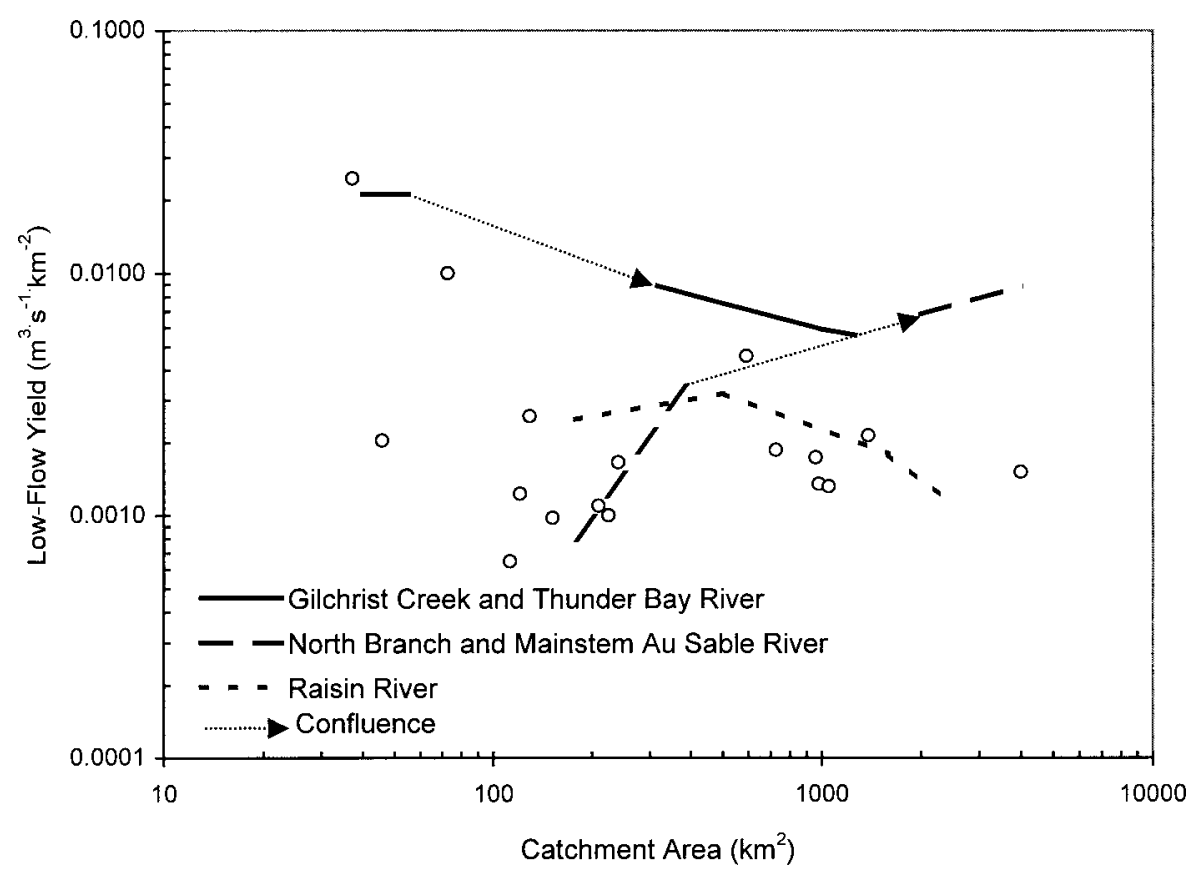

FIGURE 9.-Longitudinal changes in low-flow yield (LFY) and catchment area (CA) conditions of three lower Michigan rivers. Along each river, LFY was measured or modeled and CA was measured. Open circles represent the mean LFY and CA conditions where each cluster of fishes was most abundant (see Figure 6). Downstream changes in the proximity of a stream's LFY-CA value to the LFY-CA optima of fish clusters relate to changes in fish community structure. Note the abrupt combination of habitat conditions occurring at the confluence of tributary and main-stem reaches.

LFY, CA, and stream temperature. For example, upstream riparian shading, local groundwater inputs, and the presence of upstream wetlands, lakes, or impoundments can affect stream temperature (Wehrly et al. 1998).

\section{Longitudinal Zonation Patterns in Michigan}

Streams in glaciated areas such as lower Michigan often do not display the typical longitudinal patterns (i.e., cold, high-gradient creeks grading into warm, low-gradient rivers) described by some authors (e.g., Hawkes 1975; Vannote et al. 1980). This region contains various types of glacial deposits and soil textures in a patchwork that seems to preclude description of streams using a single generalized pattern of longitudinal zonation. These features include end and ground moraines containing particles ranging in texture from clay to boulders, glacial outwash plains and channels consisting of coarse sands and gravels, and flat glacial lakebeds of clay. Consequently, some streams have warm headwaters and cool lower reaches; others are cold upstream and warm downstream or alternate between thermal states depending upon characteristics of the landscape. Some investigators (e.g., Balon and Stewart 1983; Wiley et al. 1990) have challenged the idea that all streams share similar longitudinal patterns and suggested the need for more mechanistic approaches to explaining patterns in fish assemblage structure.

By characterizing a river's hydrology and size, the LFY-CA axes provide a useful macrohabitat template for depicting longitudinal changes in fish assemblages that occur in Midwestern rivers. Descriptions of some lower Michigan rivers demonstrate this (Figure 9). Many northeast Michigan tributaries to Lake Huron initially flow off coarsetextured outwash deposits but drain relatively flat, lacustrine sand and gravel deposits further downstream. For example, Gilchrist Creek, an upstream tributary of the Thunder Bay River is groundwaterdominated and characterized by a coldwater fish assemblage, whereas its receiving water is warmed by lakes, receives more runoff, and has mostly coolwater and warmwater fishes. Higher species richness occurs near the confluence of these two dissimilar streams due to combination of their different fish assemblages (Figure 9). Increased species richness would generally be expected at the confluence of streams having CA and LFY values 
that place them far apart in LFY-CA space. Many streams in north-central lower Michigan, such as the North Branch Au Sable River and the Au Sable River, originate in lakes and marshes within outwash plains (Figure 9). These streams initially provide warmwater conditions but become colder as their valleys descend through outwash plains and coarse-textured moraines. Going downstream, clusters having predominant fishes in the assemblages of these streams progress from creek chub and mottled sculpin, to brown trout and brook trout, to silver redhorse and logperch. Several southeast Michigan streams, including the Raisin River, originate in deposits of coarse-textured glacial tills and outwash, but drain lakeplain clays in their lower reaches (Figure 9). Low-flow yield values and fish assemblages show the river's change from small and cool upstream to larger and highly runoff-dominated downstream. By providing a common framework for comparing streams, the LFY-CA axes have helped in assessing the physical and biological potential of Michigan rivers, thus allowing fishery managers to better explain, justify, and build public support for river management plans and actions.

\section{Limitations}

Although the fish clusters explained considerable variation within the MRI data set, they provide only a very generalized and abstracted model of Michigan stream fish assemblage structure. The 17 clusters identified in this study explained about $39 \%$ of the variation in fish distributions among the 226 MRI sites, and identify several meaningful groupings of fishes. However, analyses of regression slopes demonstrated that the macro-habitat guilds did not equally represent the patterns in abundance of their constituent fishes (Table 1). We found differences in slopes among species within clusters for 11 of 17 clusters (or 54 of the 69 species) studied. This is similar to Strauss' (1982) analysis of Pennsylvania streams, in which only 27 out of 43 fishes used were included in statistically significant clusters. These findings suggest that models incorporating species-specific preferences for physical and biotic conditions may better explain distributions of fishes. We are presently developing species-specific models for fishes in Michigan rivers.

Our experience with generating clusters also suggested that cluster membership of some fishes should be viewed as tenuous. Cluster membership was generally more stable for headwater fishes than for fishes typical of large rivers, possibly be- cause of the greater range of physical conditions in lower Michigan's small streams. Because they were generated from summer field survey data, the clusters identified here represent groups of species whose abundances during the growing season were correlated. Because of seasonal differences in movement and habitat use among species, different species clusters might have been identified if fish abundance data from other seasons were included in this analysis.

We believe the approach of using LFY and CA as ordination axes for contrasting streams and displaying fish abundance patterns is widely applicable. These axes should be especially useful in geologically patchy regions, such as glaciated areas. The LFY and CA axes appear to work well in lower Michigan because they explain much of the variation in stream temperatures in the region. Empirical relationships among LFY, CA, and fish abundances that we describe, however, are specific to lower Michigan because air and groundwater temperatures (and resulting stream temperatures) vary regionally. For example, two streams, one in Michigan's Upper Peninsula and the other in southern Ohio, might have identical LFY and CA characteristics but quite different stream temperature conditions and fish assemblages. Still, the LFY-CA approach could be used to develop models specific to other regions that relate fish abundances to LFY and CA.

The LFY-CA habitat axes are valuable because they integrate many important features of stream habitats. However, as integrative variables, LFY and CA do not distinguish which particular factor may be limiting fish abundances at a particular site. In addition, LFY and CA do not account for local factors that may influence stream conditions and fish assemblage structure at sites. Such factors include groundwater inputs, substrate conditions, woody debris, dams, and lakes. Nevertheless, the LFY-CA axes provide a useful framework for describing individual streams within a geographically broader context, for characterizing a stream's biological potential, and for suggesting large-scale constraints upon a system.

\section{Utility in Management and Restoration Work}

Despite the caveats outlined above, the identification of macrohabitat guilds and their ordination on simple but meaningful habitat axes provide a useful, though very generalized, description of the way stream fish assemblage structure varies across lower Michigan rivers. Because it is derived from an extensive regional sample, the ordination rep- 
resents a kind of empirical database model, which has already proved useful in several regional management and restoration scenarios. The ordination, for example, can be used in a predictive mode by writing simple code (in Microsoft Excel or other programmable environment) to determine which guilds are likely to occur at a site with a given catchment area and base-flow yield. Evaluation can be based on any simple variance-based test to determine whether a site falls within the range of optimal axes values for each guild (e.g., within 1 SD or any error bound of choice). Expectations about the macrohabitat guilds likely to occur at a site provide a general evaluation of the potential fish community for the site, and even a preliminary list of species that could occur. Because guilds with high degrees of overlap in the ordination space need not necessarily occur together, the potential taxa list identified in this way can be expected to be larger than would actually occur at any site. Nonetheless, expectations about the species structure for a given site can be generated from macrohabitat descriptions (CA and LFY) easily obtainable for any site in the region.

We have, for example, used this approach to develop fish community restoration targets for the highly urbanized Rouge River, which drains much of metropolitan Detroit, Michigan (Wiley et al. 1998). Federally mandated expenditures of U.S.\$300 million to correct massive water quality impairments associated with sewage overflows needed site-specific biological targets to help define water quality and hydrologic design endpoints. The ordination-based model described here provided a consistent and regionally based approach to specifying which sport fishery taxa could reasonably be expected to flourish if future water quality and hydrologic regimes could be improved at a series of index sites across the catchment. Because the Rouge River is a relatively small river located on Lake Erie lakeplain, LFY values are low (averaging roughly $0.001 \mathrm{~m}^{3} \cdot \mathrm{s}^{-1} \cdot \mathrm{km}^{-2)}$; potential species of fisheries included rock bass, northern pike, bullheads, common carp, and, in the lower reaches of the river, smallmouth bass. We have used the same approach to evaluate the coldwater fisheries potential of a publicly owned reach of a Lake Michigan tributary that was receiving significant point source discharges from an agricultural packing plant (Wiley and Seelbach 1997) and in a restoration planning study evaluating the potential effects of dam removal on the upstream fish communities (Seelbach and Wiley 1996). The macrohabitat guilds described here have also been used to summarize fish assemblages in the stream classification system used for fisheries management planning by MDNR (Seelbach et al. 1997). In all of these cases, the simplification introduced by the use of macrohabitat guilds and the heuristic value of easily visualized ordination axes has proven particularly valuable in discussions with managers and the general public.

\section{Acknowledgments}

Field survey data used here were collected by Michigan Department of Natural Resources Fisheries Division field crews over the last several decades and more recently by crews based out of the University of Michigan and Institute for Fisheries Research. J. Fay (the University of Michigan GIS Laboratory) obtained summaries of catchment characteristics for modeling. Insights regarding large-scale patterns and processes of Michigan rivers were drawn from an unpublished manuscript by T. C. Dewberry (Pacific Rivers Council, Eugene, Oregon). K. Wehrly provided predicted temperatures. J. Warner (University of Michigan Center for Statistical Consultation and Research) suggested the ANOVA technique for evaluating the cluster analysis, and R. Lockwood provided helpful advice regarding regression techniques. J. Gapczynski helped build the initial fish databases. Comments by four anonymous reviewers improved the manuscript, and R. Clark, J. Diana, A. Jensen, and G. Smith provided useful editorial suggestion.

\section{References}

Aadland, L. P. 1993. Stream habitat types: their fish assemblages and relationship to flow. North American Journal of Fisheries Management 13:790-806.

Bachman, R. A. 1984. Foraging behavior of free-ranging wild and hatchery brown trout in a stream. Transactions of the American Fisheries Society 113: $1-32$.

Balon, E. K., and D. J. Stewart. 1983. Fish assemblages in a river with unusual gradient (Luongo, AfricaZaire system), reflections on river zonation, and description of another new species. Environmental Biology of Fishes 9:225-252.

Bayley, P. B., and H. W. Li. 1994. Riverine fishes. Pages 251-281 in P. Calow and G. E. Petts, editors. The rivers handbook. Blackwell Scientific Publications, Oxford, UK.

Becker, G. C. 1983. Fishes of Wisconsin. University of Wisconsin Press, Madison.

Bowlby, J. N., and J. C. Roff. 1986. Trout biomass and habitat relationships in southern Ontario streams. Transactions of the American Fisheries Society 115: 503-514.

Brett, J. R. 1979. Environmental factors and growth. 
Pages 599-675 in W. S. Hoar, D. L. Randall, and J. R. Brett, editors. Fish physiology, volume 8. Academic Press, New York.

Degerman, E., and B. Sers. 1992. Fish assemblages in Swedish streams. Nordic Journal of Freshwater Research 67:61-71.

Godin, J. J., and R. W. Rangeley. 1989. Living in the fast lane: effects of cost of locomotion on foraging behaviour in juvenile Atlantic salmon. Animal Behaviour 37:943-954.

Gordon, N. D., T. A. McMahon, and B. L. Finlayson. 1992. Stream hydrology: an introduction for ecologists. Wiley, New York.

Halliwell, D. B. 1989. A classification of streams in Massachusetts: to be used as a fisheries management tool. Doctoral dissertation. University of Massachusetts, Amherst.

Hawkes, C. L., D. L. Miller, and W. G. Layher. 1986. Fish ecoregions of Kansas: stream fish assemblage patterns and associated environmental correlates. Environmental Biology of Fishes 17:267-279.

Hawkes, H. A. 1975. River zonation and classification. Pages 312-374 in B.A. Whitton, editor. River ecology. University of California Press, Berkeley.

Hendrickson, G. E., and C. J. Doonan. 1972. Hydrology and recreation on the cold-water resources of Michigan's southern peninsula. U.S. Geological Survey and Michigan Geological Survey, Water Information Series Report 3, Lansing.

Horwitz, R. J. 1978. Temporal variability patterns and the distribution patterns of stream fishes. Ecological Monographs 48:307-321.

Huet, M. 1959. Profiles and biology of Western European streams as related to fish management. Transactions of the American Fisheries Society 88:155163.

Hughes, R. M., and J. M. Omernik. 1983. An alternative for characterizing stream size. Pages 87-101 in T. D. Fontaine III and S. M. Bartell, editors. Dynamics of lotic ecosystems. Ann Arbor Press, Ann Arbor, Michigan.

Hynes, H. B. N. 1970. The ecology of running waters. University of Toronto Press, Toronto.

Kalleberg, H. 1958. Observations in a stream tank of territoriality and competition in juvenile salmon and trout. Institute of Freshwater Research Drottningholm Report 39:55-98.

Kuehne, J. S. 1962. A classification of streams, illustrated by fish distribution in an eastern Kentucky creek. Ecology 43:608-614.

Larson, G. L., and S. E. Moore. 1985. Encroachment of exotic rainbow trout into stream populations of native brook trout in the southern Appalachian mountains. Transactions of the American Fisheries Society 114:195-203.

Legendre, P., and V. Legendre. 1984. Postglacial dispersal of freshwater fishes in the Quebec peninsula. Canadian Journal of Fisheries and Aquatic Sciences 41:1781-1802.

Lyons, J. 1989. Correspondence between the distribution of fish assemblages in Wisconsin streams and
Omernik's ecoregions. American Midland Naturalist $122: 163-182$.

Lyons, J. 1996. Patterns in the species composition of fish assemblages among Wisconsin streams. Environmental Biology of Fishes 45:329-341.

Magnuson, J. J., L. B. Crowder, and P. A. Medvick. 1979. Temperature as an ecological resource. American Zoologist 19:331-343.

Matthews, W. J., and H. R. Robison. 1988. The distribution of the fishes of Arkansas: a multivariate analysis. Copeia 1988:358-374.

Matthews, W. J., and J. T. Styron, Jr. 1981. Tolerance of headwater vs. mainstream fishes for abrupt physicochemical changes. American Midland Naturalist 105:149-158.

Meisner, J. D., J. L. Goodier, H. A. Regier, B. J. Shuter, and W. J. Christie. 1987. An assessment of the effects of climate warming on Great Lakes basin fishes. Journal of Great Lakes Research 13(3):340-352.

Meisner, J. D., J. S. Rosenfeld, and H. A. Regier. 1988. The role of groundwater in the impact of climate warming on stream salmonids. Fisheries 13(3):2-8.

Moyle, P. B., and H. W. Li. 1979. Community ecology and predator-prey relations in warmwater streams. Pages 171-180 in H. Clepper, editor. Predator-prey systems in fisheries management. Sport Fishing Institute, Washington, D.C.

Peterson, J. T., and C. F. Rabeni. 1996. Natural thermal refugia for temperate warmwater stream fishes. North American Journal of Fisheries Management 16:738-746.

Pielou, E. C. 1984. The interpretation of ecological data. Wiley, New York.

Poff, N. L., and J. D. Allan. 1995. Functional organization of stream fish assemblages in relation to hydrological variability. Ecology 76:606-627.

Poff, N. L., and J. V. Ward. 1989. Implications of streamflow variability and predictability for lotic community structure: a regional analysis of streamflow patterns. Canadian Journal of Fisheries and Aquatic Sciences 46:1805-1818.

Poff, N. L., and J. V. Ward. 1990. Physical habitat template of lotic systems: recovery in the context of historical pattern of spatiotemporal heterogeneity. Environmental Management 14(5):629-645.

Power, M. E., W. J. Matthews, and A. J. Stewart. 1985. Grazing minnows, piscivorous bass, and stream algae: dynamics of a strong interaction. Ecology 66 : 1448-1456.

Rahel, F. J., and W. A. Hubert. 1991. Fish assemblages and habitat gradients in a Rocky Mountain-Great Plains stream: biotic zonation and additive patterns of community change. Transactions of the American Fisheries Society 120:319-332.

Ricker, W. E. 1934. An ecological classification of certain Ontario streams. University of Toronto Studies, Biological Series 37. (Publication of the Ontario Fisheries Research Laboratory 49.)

Rose, D. R., and A. A. Echelle. 1981. Factor analysis of associations of fishes in Little River, central Texas, with an interdrainage comparison. American Midland Naturalist 106:379-391. 
Schlosser, I. J. 1987. The role of predation in age- and size-related habitat use by stream fishes. Ecology 68:651-659.

Schlosser, I. J. 1990. Environmental variation, life history attributes, and community structure in stream fishes: implications for environmental management and assessment. Environmental Management 14(5): 621-628.

Seelbach, P. W., R. N. Lockwood, and J. R. Ryckman. 1994. Efficiency of sampling river fishes with rotenone. Michigan Department of Natural Resources, Fisheries Research Report 2009, Ann Arbor.

Seelbach, P. W., G. L. Towns, and D. D. Nelson. 1988. Guidelines for sampling warmwater rivers with rotenone. Appendix 17 in J. W. Merna, editor. Manual of fisheries survey methods. Michigan Department of Natural Resources, Fisheries Management Report 9, Ann Arbor.

Seelbach, P. W., and M. J. Wiley. 1996. An assessment of the potential for ecological rehabilitation and restoration in Mill Creek. Report to Huron River Watershed Council for the Middle Huron Watershed Initiative, Ann Arbor, Michigan.

Seelbach, P. W., and M. J. Wiley. 1997. Overview of the Michigan Rivers Inventory Project. Michigan Department of Natural Resources, Fisheries Division Technical Report 97-3, Ann Arbor.

Seelbach, P. W., M. J. Wiley, J. C. Kotanchik, and M. E. Baker. 1997. A landscape-based ecological classification system for river valley segments in lower Michigan. Michigan Department of Natural Resources, Fisheries Research Report 2036, Ann Arbor.

Shuter, B. J., J. A. MacLean, F. E. J. Fry, and H. A. Regier. 1980. Stochastic simulation of temperature effects on first-year survival of smallmouth bass. Transactions of the American Fisheries Society 109: $1-34$.

Smale, M. A., and C. F. Rabeni. 1995a. Hypoxia and hyperthermia tolerances of headwater stream fishes. Transactions of the American Fisheries Society 124: 698-710.

Smale, M. A., and C. F. Rabeni. 1995b. Influences of hypoxia and hyperthermia on fish species composition in headwater streams. Transactions of the American Fisheries Society 124:711-725.

Smith, G. R., and D. R. Fisher. 1970. Factor analysis of distribution patterns of Kansas fishes. Pages 259277 in W. Dort, Jr., and J. K. Jones, Jr., editors. Pleistocene and recent environments of the central Great Plains. University of Kansas, Department of Geology, Special Publication 3, Lawrence.

Southwood, T. R. E. 1977. Habitat, the templet for ecological strategies? Journal of Animal Ecology 46: 337-365.

SPSS. 1993. SPSS for Windows, release 6.0. SPSS, Chicago.

Starrett, W. C. 1951. Some factors affecting the abundance of minnows in the Des Moines River, Iowa. Ecology 32:13-27.

Staso, J. D., III, and F. J. Rahel. 1994. Influence of water temperature on interactions between juvenile Col- orado River cutthroat trout and brook trout in a laboratory stream. Transactions of the American Fisheries Society 123:289-297.

Strauss, R. E. 1982. Statistical significance of species clusters in association analysis. Ecology 63:634639.

Trautman, M. B. 1981. Fishes of Ohio. Ohio State University Press, Columbus (revised).

Van Deusen, R. D. 1954. Maryland freshwater stream classification, by watersheds. University of Maryland, Chesapeake Biological Laboratory, State of Maryland Board of Natural Resources Department of Research and Education Contribution Number 106, Solomons.

Vannote, R. L., G. W. Minshall, K. W. Cummins, J. R. Sedell, and C. E. Cushing. 1980. The river continuum concept. Canadian Journal of Fisheries and Aquatic Sciences 37:130-137.

Ward, J. V., and J. A. Stanford. 1983. The intermediatedisturbance hypothesis: an explanation for biotic diversity patterns in lotic ecosystems. Pages 347-356 in T. D. Fontaine and S. M. Bartell, editors. Dynamics of lotic ecosystems. Ann Arbor Science, Ann Arbor, Michigan.

Waters, T. F. 1983. Replacement of brook trout by brown trout over 15 years in a Minnesota stream: production and abundance. Transactions of the American Fisheries Society 112:137-146.

Wehrly, K. E., M. J. Wiley, and P. W. Seelbach. 1998. Landscape-based models that predict July thermal characteristics of Lower Michigan rivers. Michigan Department of Natural Resources, Fisheries Research Report 2037, Ann Arbor.

Wiley, M. J., S. L. Kohler, and P. W. Seelbach. 1997. Reconciling landscape and local views of aquatic communities: lessons from Michigan trout streams. Freshwater Biology 37:133-148.

Wiley, M. J., L. L Osborne, and R. W. Larimore. 1990. Longitudinal structure of an agricultural prairie river system and its relationship to current stream ecosystem theory. Canadian Journal of Fisheries and Aquatic Sciences 47:373-384.

Wiley, M. J., and P. W. Seelbach. 1997. An ecological assessment of opportunities for fishery rehabilitation in the Pigeon River, Ottawa County. Report to Pigeon River Watershed Advisory Council, Grand Haven, Michigan.

Wiley, M. J., P. W. Seelbach, and S. P. Bowler. 1998. Ecological targets for rehabilitation of the Rouge River. Rouge Project Office, Special Report RPOPI-SR21.00, Detroit, Michigan.

Zalewski, M., and R. J. Naiman. 1985. The regulation of riverine fish communities by a continuum of abiotic-biotic factors. Pages 3-9 in J. S. Alabaster, editor. Habitat modification and freshwater fisheries. Food and Agriculture Organization of the United Nations, EIFAC/85, Rome.

Zippen, C. 1958. The removal method of population estimation. Journal of Wildlife Management 22:8290.

Zorn, T. G., and P. W. Seelbach. 1995. The relation between habitat availability and the short-term car- 
rying capacity of a stream reach for smallmouth bass. North American Journal of Fisheries Management 15:773-783.

Zorn, T. G., P. W. Seelbach, and M. J. Wiley. 1998.
Patterns in the distributions of stream fishes in Michigan's lower peninsula. Michigan Department of Natural Resources, Fisheries Research Report 2035, Ann Arbor. 